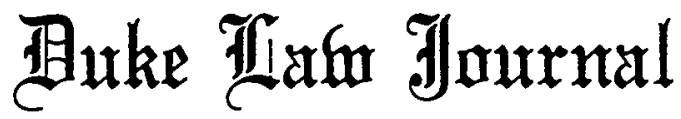

\begin{tabular}{lll}
\hline VOLUME 1983 & APRIL & NUMBER 2 \\
\hline
\end{tabular}

\section{LEGISLATIVE COURTS, ADMINISTRATIVE AGENCIES, AND THE NORTHERN PIPELINE DECISION}

\author{
MARTIN H. REDISH*
}

In Northern Pipeline Construction Co. v. Marathon Pipe Line Co., the Supreme Court held unconstitutional the exercise of the jurisdiction of the Bankruptcy Courts because their judges lacked article III's protections of salary and tenure. In so holding, the Court signifcantly altered the criteria for deciding what cases have to be heard by judges with article III protections. In this article, Professor Redish criticizes the criteria adopted by the Justices, and suggests alternative criteria which would better foster the values behind the independence protections of article III. In addition, he examines the implications of the various criteria for the continued use of administrative agencies as adjudicators of federal law.

"Legislative courts are but agencies in drag . . . ."1

Article III, section 1 of the Constitution provides that the "judicial Power of the United States shall be vested ini one suprenie Court, and in such inferior Courts as the Congress niay from time to time ordain and establish," and that the judges of both the Supreme Court and the inferior federal courts "shall hold their Offices during good Behaviour, and shall, at stated Times, receive for their Services, a Compensation, which shall not be diminished during their Continuance in Office."2 Section 2 of article III lists all of the categories of cases to which the "judicial power" extends. Congress need not have created inferior federal courts and could instead have chosen to rely upon the state courts

- Professor of Law, Northwestern University. The author would like to express his thanks to Yvette Ehr of the class of 1984 at Northwestern University School of Law for her invaluable research assistance.

1. Karst, Federal Jurisdiction Haiku, 32 StaN. L. REv. 229, 230 (1979).

2. U.S. CoNST. art. III, 81. 
for at least an initial ${ }^{3}$ adjudication of federal law. ${ }^{4}$ However, a reasonable reading of article III demonstrates that if and when Congress does create inferior courts to exercise the judicial power, the judges of those courts must have their salary and tenure protected.

Nevertheless, since early in the nation's history, the Supreme Court has recognized that Congress inay, as an exercise of one or another of its enumerated powers, create courts whose judges do not receive the article III salary and tenure protections. Because Congress will usually einploy one of its enumerated powers in article $I, 5$ in combination with the "necessary-and-proper" clause of that same article, ${ }^{6}$ as the source of its authority to create these courts, ${ }^{7}$ they are referred to as "article I" courts or "legislative courts."

The opinion of Chief Justice Marshall in American Insurance Co. v. Canter, ${ }^{9}$ is the earhiest and perhaps most memorable decision of the Court in the line of cases concerning this subject. In Canter, the Court held that Congress could properly constitute the courts of the territories as non-article III "legislative" courts. ${ }^{10}$ Since that time, however, it has never been entirely clear under what circumstances Congress could em-

3. Less clear is Congress' authority to limit the Supreme Court's appellate jurisdiction. Although article III, section 2 provides that the Court's appellate jurisdiction is subject to such "Exceptions, and under such Regulations" as Congress shall make, the scope of this clause has never been fully defined, and certain commentators have argued that Congress' power is severely restricted. See, e.g., Ratner, Congressional Power Over the Appellate Jurisdiction of the Supreme Court, 109 U. PA. L. Rev. 157 (1960). See generally Redish, Congressional Power to Regulate Supreme Court Appellate Jurisdiction Under the Exceptions Clause: An Internal and External Examination, 27 VIIL. L. REv. 900 (1982).

4. See, eg., Sheldon v. Sill, 49 U.S. (8 How.) $441,448-49$ (1850). See generally Hart, The Power of Congress to Limit The Jurisdiction of Federal Courts: An Exercise in Dialectic, 66 HARv. L. REv. 1362 (1953).

5. U.S. CONST. art. I, \& 8 .

6. Id cl. 18.

7. It should be noted that although article $I$, section 8 grants Congress the power "To constitute Tribunals inferior to the supreme Court," this power concerns the creation of the inferior article III courts, rather than legislative courts. See Gliden Co. v. Zdanok, 370 U.S. 530, 543 (1962).

8. See M. Redish, Federal Jurisdiction: Tensions in the Allocation of Judicial POWER 35 (1980). It should be noted, however, that although legislative courts will generally be created pursuant to one of Congress' article I powers, this is not always the case. For example, Congress' power to create territorial courts is derived from article IV, section 3 of the Constitution, which provides that "[t]he Congress shall have Power to dispose of and make all needful Rules and Regulations respecting the Territory or other Property beionging to the United States . . . ."

9. 26 U.S. (1 Pet.) 511 (1828).

10. The facts of Canter, which are of no particular importance for present purposes, are well described in C. WrIGHT, LAW OF FEDERAL CoURTS 40-41 (4th ed. 1983). 
ploy non-article III courts to adjudicate cases falling within the terms of the judicial power. ${ }^{11}$

Part of the lack of clarity stems from Chief Justice Marshall's statement in Canter that legislative courts did not, and could not, exercise the "judicial power" of article III,"12 even though the types of cases heard by the territorial courts did not seem to differ from the traditional cases adjudicated by the article III courts. In subsequent decisions, the Supreme Court has held that legislative courts can exercise any article III power that is not "inherently judicial," 13 that they cannot exercise any article III power, ${ }^{14}$ and that it is uncertain whether legislative courts are capable of exercising "inherently judicial" article III power. ${ }^{15}$ To complicate matters further, the Court lias never defined the term "inherently judicial."16

The greatest potential practical problem caused by this state of confusion concerns the work of federal administrative agencies. ${ }^{17} \mathrm{Al}-$ though such agencies do not function as "courts," they nevertheless are "non-article III" bodies in inucli the same sense as are the less common ${ }^{18}$ legislative courts; the personnel of both do not liave the salary and tenure protections of article III. Nonetheless, agencies arguably adjudicate 19 "cases" that "arise under" the laws of the United States, and these cases constitute one of the central categories of the article III judicial power. ${ }^{20} \mathrm{~A}$ broad holding that non-article III bodies are incapable of exercismg the article III judicial power might radically alter or

11. As Justice Rehnquist correctly noted in his concurring opinion in Northern Pipeline Constr. Co. v. Marathon Pipeline Co., 102 S. Ct. 2858, 2881 (1982), "[t]he cases dealing with the authority of Congress to create courts othcr than by use of its power under Art. III do not admit of easy synthesis."

12. "The jurisdiction with which [legislative courts] are invested, is not a part of that judicial power which is defined in the $3 \mathrm{~d}$ article of the Constitution, but is conferred by Congress in the execution of those general powers which that body possesses over the territories of the United States." 26 U.S. (1 Pet.) at 546.

13. Ex parte Bakelite Corp., 279 U.S. 438, 450 (1929).

14. Williams v. United States, 289 U.S. 553, 578-79 (1933).

15. Glidden Co. v. Zdanok, 370 U.S. 530, 549 (1962).

16. See D. Currie, Federal JuRisdiction IN A Nutshell 37 (1976) (referring to the concept of "inherently judicial, whatever that means)."

17. The word "potential" should be emphasized for, as will be seen, to date such difficulties have not developed, though perhaps they logically should have. See infra text accompanying notes $117-44$.

18. Currently, there are relatively few so-called "legislative" courts in existence. Basically, the category includes the territorial courts, the military courts, the courts of the District of Columbia and the Tax Court.

19. To the extent agencies perform ouly a rulemaking function, there would not seen to be a problem. See infra note 115.

20. See, eg., Mishkin, The Federal "Question" in the District Courts, 53 Colum. L. Rev. 157, 157 (1953) ("with the expanding scope of federal legislation, the exercise of power over cases of this sort constitutes one of the major purposes of a full independent systen of national trial courts"). 
curtail the functioning of these agencies. On the other hand, a holding that non-article III bodies could exercise unlimited article III authority would effectively gut the article III salary and tenure protections by facilitating congressional circumvention of those protections.

In 1982, the Supreme Court added to this already confusing situation with its decision in Northern Pipeline Construction Co. v. Marathon Pipe Line Co. ${ }^{21}$ In Northern Pipeline a sharply divided Court ${ }^{22}$ held that the non-article III judges of the bankruptcy courts, which Congress established in the Bankruptcy Reform Act of 1978,23 could not constitutionally exercise at least a part of the jurisdiction vested in them under that Act. Although the decision has created serious and immediate problems for Congress by forcing it to restructure, under tremendous time pressure, 24 the method of bankruptcy adjudication, the ramifications of Northern Pipeline extend far beyond the case's immediate impact on the exercise of bankruptcy jurisdiction. All four opinions written in the decision are plagued by questionable reasoning. Each, in varying degree, adopts guidelines for allocating authority between article III and non-article III bodies which are without legitimate basis in logic or im constitutional language, history, or policy. In particular, Justice Brennan's conclusion for the plurality that Congrcss cannot vest a non-article III bankruptcy court with all or part of the bankruptcy jurisdiction ${ }^{25}$ should lead to the conclusion that much of the work of most federal administrative agencies is unconstitutional. Justice Bren-

21. 102 S. Ct. 2858 (1982).

22. Justice Brennan, speaking for a plurality of four Justices, announced the judgment of the Court. Justice Rehnquist, joined by Justice O'Connor, concurred separately. Justice White, joined by Justice Powell and the Chief Justice, dissented. The Chief Justice also filed a brief separate dissent.

23. Pub. L. No. 95-598, 92 Stat. 2549 (codified as amended at 11 U.S.C. $8 \S 101-151326$ (Supp. V 1981)).

24. Although the Court held the jurisdictional provision of the Act, 28 U.S.C. \& 1471 (Supp. IV 1980), unconstitutional, it stayed the effect of its order until October 4, 1982, in order to "afford Congress an opportunity to reconstitute the bankruptcy courts or to adopt other valid means of adjudication, without impairing the interim administration of the bankruptcy laws." $102 \mathrm{~S}$. Ct. at 2880. The Court's stay was extended on October 4 until December 24, 1982. 51 U.S.L.W. 3259 (U.S. Oct. 4, 1982). However, application for a further extension was denied on December 23. 51 U.S.L.W. 3475 (U.S. Dec. 23, 1982). At the time of this writing, no revising legislation has been enacted, though one house has recently passed relevant legislation. See infra note 54 . The bankruptcy courts-now, at least technically, unconstitutional-are presently operating under interim orders from the district courts.

25. Justice Brennan's decision leaves open the question whether Congress may have the traditional issues of bankruptcy and the division of the debtor's assets decided by non-article III judges. Northern Pipeline presented only the question of an article I judge's ability to adjudicate a state-created common law cause of action involving the bankrupt. $102 \mathrm{~S}$. Ct. at $2880 \mathrm{n} .40$. However, the Court found that the jurisdictional grants were not severable and therefore invalidated the entire jurisdictional provision. Id 
nan, however, explicitly rejects such a suggestion. ${ }^{26}$ But close examination of the grounds on which he attempts to distinguisl the work of these agencies shows the distinction to be unpersuasive.

Using the Northern Pipeline decision as a point of departure, this article critically explores the possible bases on which to allocate judicial authority between article III and non-article III bodies. It argues that the Court cannot logically distinguish the work of non-article III legislative courts from that of administrative adjudicatory bodies. Despite several differences im both appearance and operation, ${ }^{27}$ their work cannot be functionally or theoretically distinguished. As Professor Karst suggests in a colorful manner, ${ }^{28}$ the differences between the two types of non-article III bodies are, at least for constitutional purposes, superficial. Thus, Justice Brennan's guidelines for determining the proper division of power among article $I$ and article III courts, as well as his purported justification for the use of administrative agencies under those guidelines, ultimately prove to be unacceptable. ${ }^{29}$ Those suggested by Justice White in his dissent prove to be no better. ${ }^{30}$ The goal of this article is to suggest a more appropriate solution.

The article briefly explores the facts, holding, and reasoning in Northern Pipeline. ${ }^{31}$ It then critiques the various standards suggested im the opinions, explaining why each fails to provide an appropriate basis on which to determine the proper scope of authority of non-article III bodies. ${ }^{32}$ The article then considers the various justifications, suggested in Northern Pipeline and elsewhere, ${ }^{33}$ for agency adjudicatory power without article III salary and tenure protections. ${ }^{34}$ Finally, the article suggests two alternative methods for allocating judicial power between article III and non-article III bodies, methods preferable to those suggested by the Justices in Northern Pipeline, and considers the consequences of these rationales for federal administrative agencies. ${ }^{35}$

26. Id at 2878.

27. See infra text accompanying notes 117-20.

28. See supra text accompanying note 1.

29. See infra text accompanying notes 102-44.

30. See infra text accompanying notes $145-62$.

31. See infra text accompanying notes 36-53.

32. See infra text accompanying notes 75-144.

33. See Tushnet, Invitation to a Wedding: Some Thoughts on Article III and a Problem of Statutory Interpretation, 60 IowA L. REv. 937, 950-51 (1975), discussed infra at note 144.

34. See unfra text accompanying notes 145-62.

35. See infra text accompanying notes 163-74. 


\section{The $\dot{N}$ ORTHERN PIPELINE DeCISION}

In January of 1980, Northern Pipeline Construction Company (Northern) filed a petition for reorganization in one of the bankruptcy courts created by the 1978 Act. ${ }^{36}$ Northern then filed suit in the same court against Marathon Pipe Lime Company (Marathon) asserting a variety of common law claims, including breach of contract and misrepresentation. Marathon moved to dismiss the suit on the ground that the jurisdictional provision of the Act ${ }^{37}$ unconstitutionally conferred article III judicial power on judges who lacked the salary and tenure protections of article III. The bankruptcy court demed Marathon's motion. On appeal, however, the district court granted the motion and the Supreme Court affirmed. ${ }^{38}$ Justice Brennan, speaking for a plurality of four Justices, announced the judgment of the Court. Justice Relinquist concurred separately, ${ }^{39}$ and Justice O'Connor joined in his opinion.40 Justice White, speaking for the Chief Justice and Justice Powell, dissented, ${ }^{41}$ and the Chief Justice also authored a brief separate dissent. ${ }^{42}$

The case actually involved only the question of whether the bankruptcy courts can adjudicate state-created common law rights which

36. The Act established a bankruptcy court in each federal judicial district as an "adjunct" to the district court. The bankruptcy court judges are appointed for 14-year terms, subject to removal by the local circuit's judicial council on grounds of incompetence, misconduct, neglect of duty, or disability. Their salaries, set by statute, are subject to adjustment. Though the jurisdictional provision, 28 U.S.C. \& 1471(a) (Supp. IV 1980), initially vested jurisdiction in the federal district courts, in a later section it provides that " $[t]$ he bankruptcy court for the district in which a case under title 11 [the Bankruptcy title] is commenced shall exercise all of the jurisdiction conferred by this section on the district courts." 28 U.S.C. \& 1471(c) (Supp. IV 1980). See generally Eisen \& Smrtnik, The Bankruptcy Reform Act of 1978-An Elevated Judiciary, 28 DE PAUL L. REV. 1007 (1979).

Justice Brennan in Northem Pipeline described the pre-1978 Act procedure:

Before the Act, federal district courts served as bankruptcy courts and employed a "referee" system. Bankruptcy proceedings were generally conducted before referees, except in those instances in which a district court elected to withdraw a case from a referee. . . . The referee's final order was appealable to the district court. . . The bankruptey courts were vested with "summary jurisdiction" - that is, with jurisdiction over controversies involving property in the actual or constructive possession of the court. And, with consent, the bankruptcy court also had jurisdiction over some "plenary" matters- such as disputes involving property in the possession of a third person.

The [1978] Act eliminates the referee system . . . .

The jurisdiction of the bankruptcy courts created by the Act is much broader than that exercised under the former referee system. Eliminating the distimetion between "summary" and "plenary" jurisdiction, the Act grants the new courts jurisdiction over all "civil proceedings arising under title 11 or arising in or relased to cases under title 11." 102 S. Ct. at 2862 (footnote omitted) (emphasis added by the Court).

37. 28 U.S.C. 8 1471(a) (Supp. IV 1980).

38. $102 \mathrm{~S}$. Ct. at 2864.

39. Id. at 2880.

40. $I d$

41. Id. at 2882 .

42. Id 
involve the bankrupt. 43 Justice Brennan's opinion nevertheless begins as if he were deciding much more:

The question presented is whether the assignment by Congress to bankruptcy judges of the jurisdiction granted in \$241(a) of the Bankruptcy Act of 1978 . . . violates Art. III of the Constitution. 44

The jurisdictional provision to which Justice Brennan refers describes the entire jurisdiction of the bankruptcy courts. ${ }^{45}$ The reasoning in his opinion demonstrates, however, that Justice Brennan's ultimate conclusion is not as broad as his initial question.

Brennan first states that Northern Pipeline differs from cases upholding the use "of legislative courts and administrative agencies to adjudicate cases involving 'public rights' "46 because Northern Pipeline involves only so-called "private" rights. He asserts that although "the restructuring of debtor-creditor relations . . . . may well be a "public right," "the type of common law adjudication involved in Northern Pipeline "obviously is not." 47 Drawing on Chief Justice Hughes' famed opinion in Crowell v. Benson, 48 Brennan concludes that cases adjudicating so-called "public rights" arc those "arising "betwcen the Government and persons subject to its authority in connection with the performance of the constitutional functions of the executive or legislative departments." "49 The adjudication of sucl rights, Justice Brennan writes, is not "inherently judicial"; such rights therefore may be adjudicated by an article III court if Congress so desires, but they need not be. ${ }^{50}$ "Inherently judicial" cases, on the other hand, are disputes between private litigants or private rights disputes. According to Justice Brennan, such cases "lie at the core of the historically recognized judicial power,"s1 and must, therefore, be heard by an article III court. 52 Thus, despite his broad opening statement, Justice Brennan never decided whether a non-article III bankruptcy court could constitutionally perform the traditional functions of dividing a bankrupt debtor's assets among its creditors and discharging the bankrupt. As the Chief Justice accurately remarks in dissent:

[T]he Court's holding is limited to the proposition . . . that a "traditional" state common law action, not made subject to a federal rule

43. Id. at 2864,2878 ; cf. id. at 2882.

44. Id. at 2862.

45. 28 U.S.C. $81471(\mathrm{a})$ (Supp. IV 1980).

46. $102 \mathrm{~S}$. Cl. at 2869.

47. Id. at 2871.

48. 285 U.S. 22 (1932).

49. 102 S. C. at 2869 (quoting Crowell v. Benson, 285 U.S. 22, 50 (1932)).

50. Id at 2869-70.

51. Id at 2871.

52. Id. at 2871. 
of decision, and related only peripherally to an adjudication of bankruptcy under federal law, must, absent the consent of the litigants, be heard by an "Article III court" if it is to be heard by any court or agency of the Umited States. 53

The Northern Pipeline decision creates serious and acute problems for Congress and for the future of all federal bankruptcy adjudication. ${ }^{54}$ Of considerably greater concern, however, are the implications for the conceptual basis on which to determine the proper scope of the "judicial power" to be exercised by non-article III bodies. By invoking a dichotomy between so-called "public" and "private" rights, the Court has introduced (or, perhaps more accurately, reintroduced) a standard wholly unwarranted by constitutional language, history, policy or theory. In an almost perverse way, the standard locates cases that are, at best, peripheral to the scope of article III at the "core" of the federal judicial power.

\section{The Public-Private Right Dichotomy: A Critique}

If Justice Brennan's opimion becomes accepted precedent, 55 the public-private right dichotony will be the standard for determining the

53. Id. at 2882 (Burger, C.J., dissenting).

54. The Court imposed an extremely restrictive time limit for congressional action, see supra note 24, and Congress' options at this point appear to be quite limited. Congress could, without any constitutional difficulty, make all bankruptcy judges article III judges. Such a plan, however, would unduly constrict Congress' future options. Also, because there are so many bankruptcy judges, such an approach uright undermine the prestige of article III judges. Alternatively, Congress could vest in the district courts the part of the bankruptcy courts' jurisdiction over statecreated common law claims involving the bankrupt; it was ouly the exercise of this jurisdiction that a majority of the Court conclusively held could not be given to non-article III judges. Such action would, however, defeat one of the primary goals of the 1978 Act by requiring adjudication of a bankruptcy dispute in more than one forum. Moreover, this option may be subject to constitutional attack because the Court has never held that article I judges can hear any matters in a bankruptcy proceeding; it is at least arguable that discharging a bankrupt's debts to his creditors involves a "private" right under Justice Brennan's definition because it involves a dispute among private individuals. Congress might be able to keep all forms of bankruptcy jurisdiction in one forum by subjecting the bankruptcy judges to the direct control of the district judge, a relationship similar to that which exists between district court judges and magistrates. In Northern Pipeline, Justice Breman contrasted the bankruptcy court system unfavorably to the inore constitutionally acceptable magistrate systein. See $102 \mathrm{~S}$. Ct. at 2877; see also United States v. Raddatz, 447 U.S. 667 (1980). However, this option would defeat Congress' original goal of increasing the status of bankruptcy adjudication. See Eisen \& Smrtnik, supra note 36, at 1010. For a discussion of congressional goals in the 1978 Act, see Keimedy, The Banksuptcy Court Under the New Bankruptcy Law: Its Structure, Jurisdiction, Venue, and Procedure, II ST. MARY's L.J. 251 (1979); Klee, Legislative History of the New Bankeruptcy Law, 28 DE PAUL L. REv. 941 (1979). As this article went to press, the Senate had recently passed S. 10I3, which attempts to avoid the problems created by Northem Pipeline by making the bankruptcy courts fnnction as true "adjuncts," and by increased use of the consent mechanism.

55. Only a plurality of the Court joined in Justice Brennan's opinion. Justice Rehnquist, however, speaking for two members of the Court, appeared to accept much of the logic behind 
division of authority between article III and article I courts. ${ }^{56}$ An examination of the history of, justifications for, and problems with this distimction demonstrates its questionable underlying reasoning.

\section{A. The History of the Dichotomy.}

Although the language and logic of article III do not justify the public-private right dichotomy, it does find a basis in Supreme Court precedent. An examination of the relevant precedents, lowever, demonstrates that they did not bind the Court to adopt the public-private right dichotomy as the standard for determining the appropriate scope of article I court authority.

The origin of the diclotomy appears to be the following mid-nineteenth century statement by Justice Curtis in Murray's Lessee v. Hoboken Land \& Improvement Co. :57 $^{5}$

[W] do not consider congress can either withdraw from judicial cognizance any matter which, from its nature, is the subject of a suit at the common law, or in equity, or admiralty; nor, on the other hand, can it bring under the judicial power a matter which, from its nature, is not a subject for judicial determination. At the same time there are matters, involving public rights, which may be presented in such fonn that the judicial power is capable of acting on them, and which are susceptable of judicial determination, but which congress may or may not bring within the cognizance of the courts of the United States, as it may deem proper. $^{.8}$

Notably, Justice Curtis makes no reference to the language, history, or pohicies of article III to support his suggested dichotomy. ${ }^{59}$ Therefore, nothing but blind adherence to antiquated dicta-something for which the Supreme Court is certainly not known ${ }^{60}$-justifies modern acceptanee of Justice Curtis' statement. ${ }^{61}$

Brennan's "public rights" doctrine. 102 S. Ct. at 2881-82. See infra notes 97-98 and accompanying text.

56. Because Justice Brennan suggested several distinctions between article I courts and administrative agencies, $102 \mathrm{~S}$. Ct. at 2874-78; see infra text accompanying notes $129-31$, it is possible that the public-private right dichotomy will not affect the work of these agencies. However, if those distinctions are untenable, see infra text accompanying notes 132-144, then the viability of the dichotomy would directly affect the constitutional status of administrative agencies, as well as that of the legislative courts.

57. 59 U.S. (18 How.) 272 (1855).

58. Id at 284.

59. Id at 284-85.

60. Traditionally, it has been thought that the doctrine of stare decisis is at its weakest when issues of constitutional law are involved. See, eg., Glidden v. Zdanok, 370 U.S. 530, 543 (1962); State Bd. of Ins. v. Todd Shipyards Corp., 370 U.S. 451, 457 (1962).

61. Nonetheless, Justice Brennan relied lieavily on this statement in his Northern Pipeline iccisiull. 
The Court cited the dichotomy created in Murray's Lessee 62 in the subsequent decisions of Ex parte Bakelite Corp. ${ }^{63}$ and Crowell v. Benson. ${ }^{64}$ In Bakelite, the Court held that because the matters heard by the Court of Customs Appeals "include nothing which inherently or necessarily requires judicial determination,"6s the court could appropriately be deemed an article I court. Citing Murray's Lessee, ${ }^{66}$ the Court stated:

Legislative courts . . may be created as special tribunals to examine and determine various matters, arising between the government and others, which from their nature do not require judicial determination and yet are susceptible of it. The mode of determining matters of this class is completely within congressional control. Congress may reserve to itself the power to decide, may delegate that power to executive officers, or may commit it to judicial tribunals. ${ }^{67}$

The Court, however, did not state explicitly that cases involving adjudication of so-called "private" rights were "inherently judicial."

In Crowell, Chief Justice Hughes referred to Murray's Lessee when he wrote that "the distinction is at once apparent between cases of private right and those.which arise between the Government and persons subject to its authority in connection with the performance of the constitutional functions of the executive or legislative departments." 68 The Court in Crowell, however, did not go so far as to hold that a nonarticle III body lacked power to adjudicate "private" rights. Although the case involved suit on a "private" right, 69 the Court held that an administrative agency could nevertheless make factual findings. ${ }^{70}$ The only constitutional limitation the Court placed on the administrative agency was that questions of both constitutional law and constitutional fact $^{71}$ must be decided de novo by an independent judiciary. ${ }^{72}$ The

62. 59 U.S. (18 How.) at 284.

63. 279 U.S. 438 (1929).

64. 285 U.S. 22 (1932).

65. 279 U.S. at 453.

66. Id at 451 .

67. Id

68. 285 U.S. at 50.

69. Crowell involved a challenge to an order of the deputy commissioner of the United States Employees' Coinpensation Commission, pursuant to the Longshorenen's and Harbor Workers' Compensation Act, against an employer for an injury to an employec. Id at 36-37.

70. Id at 46.

71. A "constitutional fact" is a factual question, the determination of which one way or the other pill determine whether a particular governmental action is constitutional. For example, if the government attempts to restrict pornographic expression, whether or not that expression is found to be legally "obscene" will determine whether such restriction is constitutional, since "obscene" expression is not protected by the first amendment.

72. 285 U.S. at 60. 
Court apparently intended this limitation to apply in both "public" and "private" right adjudications.

Atlas Roofing Co. v. Occupational Safety \& Health Review Commission, cited by Justice Brennan in Northern Pipeline, contains the most recent Supreme Court reference to the dichotomy. ${ }^{73}$ The Court in $\mathrm{At}$ las held that the seventh amendment right to jury trial in civil cases does not apply to cases imvolving a statutory cause of action vested in the federal government for civil penalties enforceable in an administrative agency. "At least in cases in which 'public rights' are being hitgated," said Justice White, "the Seventh Amendment does not prohibit Congress from assigning the factinding function and initial adjudication to an administrative forum with which the jury would be incompatible."74 The Court then added the following footnote:

These cases do not involve purely "private rights." In cases which do involve only "private rights," this Court has accepted factfinding by an administrative agency, without intervention by a jury, only as an adjunct to an Art. III court, analogizing the agency to a jury or a special master and permitting it in admiralty cases to perform the function of the special master. [citing Crowell].75

Atlas Roofing was in many ways controversial. Despite the Court's analysis, the case had nothing to do with the division of authority between article III and non-article III bodies. Rather, the case imvolved the applicability of the seventh amendment, an issue that had never been thought to turn on a public-private right distinction, but rather on an analogy to common law practice. ${ }^{76}$ Thus, the Atlas Roofing Court's reliance on the distinction in the seventh amendment context was dubious. In any event, because Atlas Roofing did not directly involve the article III-article I division of authority, the case is of minimal precedential value to the Court in Northern Pipeline.

As a unit, the precedents relied on by Justice Brennan fail to coinpel use of the public-private right dichotomy as the standard for determining the division of authority between article III and article I bodies. The precedential value of at least two of those decisions-Bakelite and Crowell-has been seriously eroded by subsequent Supreme Court decisions. ${ }^{77}$ Moreover, the Court did not atteinpt in any of these deci-

73. 430 U.S. 442 (1977).

74. Id at 450 .

75. Id at $450 \mathrm{n} .7$.

76. The seventh amendment provides that in suits "at common law," the right to civil jury trial shall be "preserved." See generally Redish, Seventh Amendment Right to Jury Trial: A Study in the Irrationality of Rational Decision Making, 70 Nw. U.L. REv. 486 (1975).

77. Justice Harlan, in Glidden Co. v. Zdanok, questioned the conclusion in Bakelite that the Court of Customs Appeals was an article 1 court. 370 U.S. 530, $549-50$ (1962). At the very least, Crowell's requireinent of a de novo learing in the article III court has been expressly rejected. St. 
sions to ground the dichotomy in the language, policies, or history of article III; Justice Curtis in Murray's Lessee appeared to do little more than assert the dichotomy, and subsequent decisions by the Court have assumed the Murray's Lessee analysis to be correct. These precedents alone cannot compel the Supreme Court to adopt the public-private right dichotomy. Therefore, unless the distinction can be justified on other grounds, it should be abandoned.

\section{B. Problems with the Dichotomy.}

Even if precedential support for the public-private right dicliotomy were stronger, the Court would not be justified in adhering to it. Use of the dichotoiny to determine the proper article III-article I division contravenes the policies and language of article III. Article III, section 2 explicitly lists the types of cases to which the federal judicial power extends. This is presumably the same judicial power vested by section 1 in courts whose judges must receive salary and tenure protections. ${ }^{78}$ The first type of cases listed are those "arising under this Constitution, the Laws of the United States, and Treaties made, or which shall be made, under their Authority. . . ."79 Such cases often involve a suit between a private individual and the government-either because the individual is challenging the government's demial of a statutory benefit ${ }^{80}$ or because the government is seeking to enforce a statutory restriction in a civil action. ${ }^{81}$ Under the public-private right dichotomy, however, most of these cases do not have to be heard by an article III court. This apparent inconsistency with constitutional language may not be sufficient to condemn the dichotomy. Only an absolutist construction of article III invalidates the vesting of any article III power in article I bodies, and the article has, rightly or wrongly, never received such a construction. ${ }^{82}$ But what makes the approval of the exercise of article I court authority over such cases so bizarre is the contrast to the type of case that the dicliotoiny dictates must be heard in article III courts: suits between private individuals involving statecreated common law rights. Such cases fall barely within the categories

Joseph Stock Yards Co. v. United States, 298 U.S. 38 (1936). Serious question has also been raised concerning the viability of the entire Crowell decision. See, e.g., K. DAVIS, ADMINISTRATIVE LAw $539-40$ (3d ed. 1972).

78. See supra text at note 2.

79. U.S. CoNST. art. III, § 1.

80. An example is a challenge to a denial of federal welfare benefits. See Goldberg v. Kelly, 397 U.S. 254 (1970).

81. An example is a cease and desist order issued by the Federal Trade Commission. 15 U.S.C. § 45(b) (Supp. V 1981).

82. See generally M. ReDish, supra note 8, at 35-51. 
of cases to which the judicial power is extended in article III, section 2. Most of these cases fall only within the diversity jurisdiction, ${ }^{83}$ although the Supreme Court has upheld, albeit cryptically, the exercise of article III court power over non-diverse common law disputes involving a bankrupt when no issue of substantive federal law is involved in the dispute. ${ }^{84}$ Such a strained use of the "arising under" jurisdiction, however, has been strongly criticized ${ }^{85}$ and is, at most, a peripheral exercise of the "arising under" jurisdiction. Thus, the cases that, according to Justice Brennan, make up the "core" of the federal judicial power, ${ }^{86}$ and therefore comprise the category of cases that may not be given for final resolution ${ }^{87}$ to an article I body, are those that barely fall within the judicial power in the first place. ${ }^{88}$

An examination of the policies behind the article III salary and tenure protections proves further the questionable nature of the dichotomy. The history of the protections is less than certain, and the modern justification for the protections is the subject of scholarly debate. ${ }^{89}$. It is not necessary to join that debate, however, to indict Justice Brennan's adoption of the public-private right dichotomy: the dichotomy is wholly imconsistent with the justifications for the protections that Justice Brennan himself invokes in Northern Pipeline.

In his explanation of the policies behind article III's salary and tenure protections, Justice Brennan initially cites Madison for the proposition that " $[t]$ he accumulation of all powers, legislative, executive, and judiciary, im the saine hands, whether of one, a few, or many, and whether hereditary, self-appointed, or elective, may justly be pronounced the very definition of tyranny." "To ensure against such tyranny," says Justice Brennan, the framers established the three distinct

83. U.S. Const. art. III, \& 2. See Mishkin, The Federal "Question" in the District Courts, 53 COLUM. L. REv. 157, 190 (1953).

84. See Williams v. Austrian, 331 U.S. 642 (1947); Schumacher v. Beeler, 293 U.S. 367 (1934).

85. See M. Redish, supra note 8, at 62-63.

86. $102 \mathrm{~S}$. Ct. at 2871.

87. For a discussion of whether the requirements of article III may be met by provision for appellate review in an article III court, see infra text accompanying notes 171-74.

88. In Northern Pipeline, Justice Brennan states that "ihe public-rights doctrine also draws upou the ... historical understanding that certain prerogatives were reserved to the political branches of government," and that "[t]he understanding of [the previous] cases is that the Framers expected that Congress would be free to commit [adjudication of public rights] completely to nonjudicial executive determination . . . "102 S. Ct. at 2869-70. However, at no point does Brennan cite any historical reference to support these assertions.

89. See, eg., Sager, Supreme Court, 1980 Term: Foreward-Constitutional Limitations on Congress' Authority to Regulate the Jurisdiction of the Federal Courts, 95 HARV. L. REv. 17 (1981).

90. THE Federalist No. 47 at 30 (J. Madison) (H. Lodge ed. 1888) (quoted in Northern Pipeline, 102 S. Ct. at 2864). 
branches of government.91 The independence protections of article III, he writes, were designed "to maintain the checks and balances of the constitutional structure, and also to guarantee that the process of adjudication itself remamed impartial." 92 Justice Brennan then quotes the following from Hamilton's Federalist Number 78:

Periodical appointments, however regulated, or by whonsoever made, would, in some way or other, be fatal to [the courts'] necessary independence. If the power of making them was committed either to the Executive or legislature, there would be danger of an improper complaisance to the branch which possessed it; if to both, there would be an unwillingness to hazard the displeasure of either; if to the people, or to persons chosen by them for the special purpose, there would be too great a disposition to consult popularity, to justify a reliance that nothing would be consulted but the Constitution and the laws. ${ }^{93}$

Thus, under Justice Brennan's own analysis, the article III independence protections are both necessary to ensure judicial integrity and " 'essential if there is a right to have claims decided by judges who are free from potential domination by other branches of government." "94

The pubhic-private right dicliotony effectively frustrates the purposes served by the constitutional protections of judicial independence. The danger of both potential federal governmental domination of the federal judiciary and potential governmental displeasure with judicial decisions is at a minimum in suits between private individuals mvolving state-created common law rights. In contrast, the types of cases in which the dangers are greatest, those involving a dispute between private individuals and the federal government, are the very cases that Justice Brennan permits article I bodies to adjudicate. Thus, as a matter of constitutional language and policy, this dichotony is a strange basis on which to erect a standard to determine the proper division of authority between article III and article I adjudicatory bodies.

\section{The Asserted Justifications for the Dichotomy.}

In a footnote to his discussion, Justice Brennan acknowledges: Doubtless it could be argued that the need for independent judicial determination is greatest in cases arising between the government and an individual. But the rationale for the public-rights line of cases hes not in political theory, but rather in Congress' and this

\footnotetext{
91. 102 S. Ct. at 2864.

92. Id.

93. The Federalist No. 78 at 489 (A. Hamilton) (H. Lodge ed. 1888) (quoted in Northern Pipeline, 102 S. Ct. at 2864-65.

94. 102 S. Ct. at 2865 (quoting United States v. Will, 449 U.S. 200, 217-18 (1980)).
} 
Court's understanding of what power was reserved to the Judiciary by the Constitution as a matter of historical fact. ${ }^{95}$

This statement is puzzling. The historical references cited by Justice Brennan ${ }^{96}$ tend to support the argument that the need for the independence protections is at a inaximum when the federal government is a party to the suit. Nevertheless, both Justice Brennan and Justice Rehnquist find historical and conceptual justifications for the dichotony. The Brennan and Rehnquist opinions seem to present two alternative rationales. One purports to explain why private rights inust be adjudicated by article III courts; the other is designed to support the conclusion that public rights need not be adjudicated by judges having the article III protection of independence.

Justice Rehnquist, who explicitly left open the question whether "public" rights could be adjudicated by non-article III bodies,97 concluded that an article III court must hear the Marathon-Northern dispute because "the lawsuit in which Marathon was namcd defendant seeks damages for breach of contract, misrepresentation, and other counts which are the stuff of the traditional actions at common law tried by the courts at Westminster in 1789."98 The point is that at the time the Constitution was written, common law disputes constituted the heart of the English judiciary's work, making it reasonable to conclude that the framers referred to such traditional judicial activity when they employed the term "judicial power," and vested that "judicial power" in the article III judiciary.

Such historical reference is explicitly incorporated by the terms of the seventh amendment when the issue of civil jury trial arises. ${ }^{99}$ There is, however, no reason to beheve the refcrence has any relevance to the division of authority betwcen article III courts and article I bodies. Had the frainers done nothing more than provide that the "judicial power" be vested in the article III courts, and left to posterity the task of defining that cryptic phrase, the argument might be somewhat persuasive. But in section 2 of article III, the franers exphicitly listed the types of cases to which the "judicial power" extends and, as noted previously, ${ }^{100}$ common law disputes between private individuals fall barely within any of the listed categories. The Court offered no specific historical reference, other than the unsupported assertions of Justice

95. $102 \mathrm{~S}$. Ct. at 2870 n. 20 .

96. See supra text accompanying notes 57-67.

97. "To whatever extent different powers granted under [the 1978] Act might be sustained under the 'public rights' doctrine. . . I I am satisfied that the adjudication of Northern's lawsuit cannot be so sustained." 102 S. Ct. at 2882 (Rehnquist, J., concurring).

98. Id. at 2881 (Rehnquist, J., concurring).

49. U.S. Const. amend. VII. See supra note 76.

100. See supro text at note 84 . 
Brennan, ${ }^{101}$ to demonstrate that the framers assumed that a group of cases so peripheral to the substance of article III would constitute the "core" of the federal judicial power.

Justice Brennan's opinion in Northern Pipeline attempts to explain why "public" right suits do not fall within article III's "core." Unlike Justice Rehnquist, he does not directly address why private rights must be adjudicated by article III courts, but concentrates instead on why public rights need not be adjudicated by such courts. The rationale appears to start with the premise that absent an affirmative exception, all of the cases falling within article III, section 2 inust be adjudicated by an article III court. Justice Brennan then finds such an affirmative ground for "public" right disputes but not for private right disputes.

The justification for excluding "public" right adjudications from article III's mandatory core, writes Justice Brennan, is "the traditional principle of sovereign immumity, which recognizes that the Government may attach conditions to its consent to be sued."102 Additionally,

the public-rights doctrine also draws upon the principle of separation of powers, and a historical understanding that certain prerogatives were reserved to the political branches of government .... [T]he Framers expected that Congress would be free to commit such matters completely to non-judicial executive determination, and that as a result there can be no constitutional objection to Congress' employing the less drastic expedient of committing their determination to a legislative court or an administrative agency. ${ }^{103}$

Justice Brennan's argument turns ultimately on this version of the deceptively attractive principle that the greater includes the lesser: because the federal government need not allow itself to be sued at all, and because Congress could either decide such matters itself ${ }^{104}$ or commit the decision completely to executive determination, it can choose the lesser step of committing the decision to an article I court or to an agency.

In the present context the "greater-includes-the-lesser" argument sinply does not work. First, the argument that the government may attach conditions to its consent to be sued disregards the well-estab-

101. 102 S. Ct. at 2871. See supra text accompanying notes 49-52.

102. $102 \mathrm{~S}$. Ct. at 2869.

103. Id at 2869-70.

104. This was, in part, the reasoning of the Court in Williams v. United States, 289 U.S. 553 (1933), in which the Court held that the Court of Claims was an article I court. Because Congress could itself "hear and determine controversies respecting claims agaimst the United States," it was proper for an article I court to adjudicate such controversies. Id. at 580-81. The Court went on, however, to conclude that because such matters could be given to an article I court, they could not be given to an article III court. Id. at 581. The Court rejected this conclusion in Glidden. 370 U.S. at 549-50. 
lished "unconstitutional conditions" doctrine. ${ }^{105}$ Congress indeed inay have no obligation to allow suit against it or to provide a statutory benefit. According to the "unconstitutional conditions" doctrine, however, once Congress allows suit against it or provides a statutory benefit, it may not condition the right to sue or the receipt of the benefit on the waiver of the imdividual's first amendment right of free expression, ${ }^{106}$ or on the stipulation that the plaintiff or recipient not be black. ${ }^{107}$ Constitutional logic should not differ when the relevant constitutional restraint is the article III protection of judicial independence, rather than the first amendinent right of free expression. Moreover, it is not clear that Congress itself could decide these issues or commit them completely to executive determination. With the exception of "private bills" enacted by Congress to compensate individuals injured by governmental action, ${ }^{108}$ it is -doubtful that Congress could legally or practically decide individual claims for or against private individuals under federal statutes. Such legislative exercises of a judicial function are arguably a violation of the doctrine of separation of powers. In any event, such a burdensome task would be well beyond the practical abilities of any legislative body, much less Congress. Finally, whether Congress itself could dispose of such "public" rights cases is logically beside the poimt. Article III does not require Congress to provide the federal courts with any of the judicial power, other than the comparatively limited original jurisdiction of the Supreme Court. ${ }^{109}$ Yet, article III does provide that, if and when Congress chooses to vest the judicial power in a federally created organ to enforce and imterpret federal law, the judges of those organs must have the specified protections of their independence. ${ }^{110}$

This reasoning does not necessarily suggest that all "public" rights disputes must be heard in an article III court if they are to be heard by a federal body at all."11 That may well be the logical result, but complicating factors make it difficult to reach that conclusion. ${ }^{112}$ Nor does this reasoning imply that the public-private right dichotomy should be adopted in a manner exactly opposite to the way it is employed by

105. See, eg., Speiser v. Randall, 357 U.S. 513 (1950).

106. See id at 528-29.

107. See generally United States v. Jefferson County Bd. of Educ., 372 F.2d 836 (5th Cir. 1966), cert. denied, 389 U.S. 840 (1967).

108. See Williams v. United States, 289 U.S. 553 (1933).

109. U.S. CoNsT. art. III, 81.

110. Id

111. See supra text accompanying notes 46-53, 71-75, 102; infra text accompanying notes 16374.

112. For example, such a conclusion might have a significant impact on the functioning of federal administrative agencies. See infra text accompanying note 171 . 
Justice Brennan (though if the dichotomy is to be used, it would make considerably more sense to reverse it). ${ }^{113}$ The point is that the dichotomy, as described by Justice Brennan im Northern Pipeline, is both irrelevant to the structure of article III and practically and theoretically anomalous.

This article explores alternative standards to determine the proper scope of authority to be exercised by non-article III bodies. ${ }^{114}$ But before undertaking this task, it is necessary to consider how rejection of the public-private right dicliotomy would affect the functioning of federal administrative agencies. Perhaps the most important practical consequence of selecting a principle to delimit the scope of authority exercised by article I bodies will be the impact the principle will have on the work of sucl agencies. The following explanation demonstrates that, absent reliance on the public-private right dichotomy, the Court's justifications for the use of administrative agencies disappear. Once this fact is established, the need to delimit the proper scope of an article I body's judicial authority will becolne even more pressing in light of the serious practical implications for the work of administrative agencies.

\section{Distinguishing the WORK of Administrative Agencies}

The members of administrative agenies do not wear robes or retain the other traditional indicia of judicial office. Nevertheless, these agencies are analagous to legislative courts because, although they may and often do perform adjudicatory functions, 115 their members do not receive the salary and tenure protections of article III. Thus, to the extent such agencies adjudicate cases arising under the laws of the United States, the difficulties facing their use may be no different from those involved in the use of inore formal legislative courts. If the only rationale for the use of legislative courts is that they are adjudicating so-called "public" rights, and that rationale is rejected,"16 the use of administrative agencies is in equal jeopardy.

Justice Brennan's opimion, however, suggests two grounds in addi-

113. The argument for abandoning the dichotomy is that the need for protecting judicial independence from being undermined by the legislative and executive branches is least important in suits between private individuals involving state-created rights; the interest of the other branches in the outcome of such cases is considerably less than when the federal government is a party to the suit, as it is by definition in a "public" rights suit.

114. See infro notes $145-74$ and accompanying text.

115. Agencies often perform a rilemaking function which is much more analogous to performance of a legislative task than to the exercise of judicial power.

116. See supra text accompanying notes 55-94. 
tion to the public-private right dichotomy ${ }^{117}$ to justify the work of those agencies and to distinguish them from the invalidated bankruptcy courts. Such agencies, states Justice Brennan, unlike the bankruptcy courts, function as "adjuncts" to the article III federal courts."18 Their functioning is legitimate because "[f]irst, it is clear that when Congress creates a substantive federal right, it possesses substantial discretion to prescribe the manner in which that right may be adjudicated-including the assignment to an adjunct of some functions historically performed by judges." 119 Second, the agencies are appropriate adjuncts because they meet the requirement that "the functions of the adjunct must be limited in sucl a way that 'the essential attributes' of judicial power are retained in the Article III court."120 If Justice Brennan's analysis is correct, administrative agencies could constitutionally perform their tasks without reliance on the public-private right dicliotomy. Absent the public rights doctrine, however, legislative courts could not function as judicial organs independent of the article III courts.

Justice Brennan's analysis justifying the use of article III "adjuncts" is, however, open to several criticisms. Brennan's first justification appears strikingly similar to the public rights doctrine:121 because Congress need not have created a substantive federal right, it can take the "lesser" action of creating the right but conditioning it on the use of a prescribed method of adjudication. Justice Brennan's second justification is that the agencies do not undermine the article III protections because an article III court ultimately exercises the judicial power. When viewed im conjunction with this second, presumably equally necessary, justification ${ }^{122}$ for the use of "adjuncts," however, the first rationale becomes puzzling. If it were logically correct that because Congress need not have created the right that it may impose conditions on the method of adjudication, it would seem to make no difference whether the adjudicator selected by Congress functioned independently of or as an adjunct to the article III federal courts. In either event, Congress' action could be justified under the logic of "the-greater-includes-the-lesser." Indeed, it was much this same rationale that Justice Brennan employed to justify, under his public rights doctrine, the use of legislative courts fully imdependent of the article III judiciary. ${ }^{123}$ Correspondingly, if, for an "adjunct" to function constitutionally, "the

117. 102 S. Ct. at 2871.

118. Id at 2875.

119. Id at 2876 (footnote omitted).

120. Id

121. See supra text accompanying notes $46-52$.

122. $102 \mathrm{~S}$. Ct. at 2876.

12j. Id. at 2870 . 
essential attributes" of the judicial power inust be retained in the article III court-as Justice Brennan posited in his second justification-why should it inake any difference whether the subject inatter of the adjunct's work is a right created by Congress? In such an event, because the article III court ultimately exercises the "judicial power," it is unclear why any further conditions inust be satisfied before the terms of article III are met. Nevertheless, Justice Brennan appeared to intertwine the two rationales as necessary but not individually sufficient conditions.

Whether or not such a combined approach was appropriate, Justice Brennan's first justification is no more persuasive in this context than it was when employed to justify the public rights doctrime. ${ }^{124}$ Equally unpersuasive is Justice Brennan's second rationale: that because the administrative agencies merely function as adjuncts to the article III court, the article III court still effectively exercises the federal judicial power, and therefore article III's salary and tenure protections are in no way nndermined by the work of such agencies. If this argument were accepted, the Court would not need to develop a basis on which to determine the proper scope of authority of non-article III bodies in order to validate the work of administrative agencies, because the article III courts would still ultimately hold the judicial power. Closer examination reveals, however, that federal administrative agencies are functionally indistinguishable from legislative courts which are subject to appellate review in an article III court.

The typical federal administrative agency is given authority to "adjudicate" individual claims either between private individuals or organizations, ${ }^{125}$ or between such private entities and the federal agency itself. ${ }^{126}$ The agency first holds hearings and finds facts. ${ }^{127}$ Ultimately, the agency apphies the law to the facts in reaching its conclusion. These activities are functions traditionally performed by courts; ${ }^{128}$ if the agencies did not exist, presumably courts would perform these functions. ${ }^{129}$

The primary functional distinction between the work of administrative agencies and that of legislative courts is that unlike courts, agen-

124. See supra notes $105-110$ and accompanying text.

125. See, eg., 29 U.S.C. $\$ \S 153-87$. (1976 \& Supp. V 1981).

126. See, eg., 15 U.S.C. $\$ \$ 41-58$ (1976 \& Supp. V 1981).

127. See, e.g., 29 U.S.C. $\$ \S 160$ (b),(c) (1976); 15 U.S.C. $\S 45$ (b) (Supp. V. 1981).

128. According to Professor Davis, courts provide agencies with considerable discretion in developing their own adjudicatory procedures. K. DAvss, supra note 77, at 212.

129. It is true that, unlike courts, agencies traditionally combine both the prosecutorial and adjudicatory functions. This fact, however, does not alter the reality that the adjudicatory functions performed by the agency would have to be performed by courts if the agency did not exist. 
cies generally cannot issue automatically enforceable orders. Rather, agencies often, though not always, ${ }^{130}$ must seek enforceinent in an article III court. ${ }^{131}$ Upon initial examination, one might conclude that the distinction is a significant one; the essential attribute of the exercise of judicial power might well be deemed the ability to issue and enforce orders. As a practical matter, however, elevating this distinction to a status of constitutional significance places form over substance. When an agency seeks enforceinent of an order in federal court, the court is required by both statute ${ }^{132}$ and precedent ${ }^{133}$ to defer to the findings and conclusions of the agency. ${ }^{134}$ Such deference is logical, in light of the accepted primciple that one purpose of administrative agencies is to have decisions made by those with the necessary expertise in the regulated subject matter. ${ }^{135}$ But one may question whether there is any difference, in terms of satisfying the article III provisions, between the requirement that the non-article III agency seek enforceinent in an article III court where that agency's findings are subject to a minimal level of review, and the roughly comparable appellate review of the automatically enforceable orders of a bankruptcy or other legislative court. The only practical difference is that in the former situation, the inertia of the initial decision hes in favor of the party that loses before the agency: if no further legal action takes place following issuance of the agency's order, that losing party will not be required to comply. In the case of the legislative court, however, the burden will be on the losing party to seek further legal action if it wishes to avoid forced compliance. But considering that it would be an absurd waste of agency time, expense, and effort to conduct an adjudicatory proceeding absent a plan to automatically take the comparatively simple step of seeking judicial enforcement (absent voluntary complance), the distinction appears considerably nore theoretical than real. ${ }^{136}$ In both situations, the non-article III body conducts the primary adjudication, makes the ba-

130. For example, orders of the Federal Trade Commission and the Interstate Commerce Commission become enforceable without judicial action if there is no appeal to an article III court. See 15 U.S.C. \& 45(g) (1976); 49 U.S.C. \& 10322(e) (Supp. V. 1980).

131. Orders of the National Labor Relations Board, for example, are not automatically enforceable. See NLRB v. Marsh Supermarkets, Inc., 327 F.2d 109, 112 (7th Cir.), cert. denied, 377 U.S. 944 (1963); 29 U.S.C. $\& 160$ (e) (1976). ("The Board shall have power to petition any court [of appeals or district court] . . . for the enforcement of such order . . . .")

132. Eg., 29 U.S.C. \& 160(e) (1976).

133. Eg., NLRB v. Bradford Dyeing Ass'n, 310 U.S. 318, 342-43 (1940).

134. See, e.g., Local 13, Detroit Newspaper Printing \& Graphic Communications Union v. NLRB, 598 F.2d 267, 272 (D.C. Cir. 1979).

135. See id; iff. FCC v. RCA Communications, 346 U.S. 86 (1953).

136. In a sense, voluntary compliance is analogous to a losing party's decision not to seek appellate review of a lower court's order. 
sic legal and factual findings, and is subject to some level of review in an article III court.

Justice Brennan purported to find important differences between review of the findings of administrative agencies by an article III court and article III court review of the findings of the bankruptcy courts. ${ }^{137}$ Although administrative findings receive "substantial evidence" review, ${ }^{138}$ findings of the bankruptcy courts were apparently subjected to what Justice Brennan deeined "the inore deferential 'clearly erroneous' standard." 139 But it is arguable that drawing a significant distinction between the two levels of scrutiny is an all but impossible task, ${ }^{140}$ and it is, in any event, questionable whether the distinction should rise to a constitutional status. More importantly, there is no inherent reasoneither theoretically or practically-why article III court review of legislative court findings could not be performed under the "substantial evidence" test, however that standard is defined. ${ }^{141}$ Thus, to the extent the Court's constitutional concern derived from the differences in scope of review, the constitutional deficiency could have been cured by ineans less drastic than invalidation of the bankruptcy courts' jurisdiction. In short, the possible differences in standards of review provide an inade-

137. Justice Brennan noted that "while orders issued by the agency in Crowell were to be set aside if 'not supported by the evidence,' the judgments of the bankruptcy courts are apparently subject to review only under the more deferential 'clearly erroneous' standard." $102 \mathrm{~S}$. Ct. at 2879.

138. The scope-of-review situation is not quite as simple as Justice Brennan implies. Subject to certain limitations imposed by section 701 , section 706 of the Administrative Procedure Act provides that a reviewing court shall "hold unlawful and set aside agency action, findings, and conclusions found to be-(A) arbitrary, capricious, an abuse of discretion, or otherwise not in accordance with law; . . . (C) in excess of statutory jurisdiction, authority, or limitations, or short of statutory right; . . . (E) unsupported by substantial evidence in a case subject to sections 556 and 557 of this title or otherwise reviewed on the record of an agency hearing provided by statute; or $(F)$ unwarranted by the facts to the extent that the facts are subject to trial de novo by the reviewing court." 5 U.S.C. 8706 (2) (1976). Section 701 provides that agency action may be "committed to agency discretion by law," in which case section 706 does not apply. Thus, at times the scope of judicial review of agency action is grcater or less than a "substantial evidence" review. See Citizens to Preserve Overton Park v. Volpe, 401 U.S. 402 (1971); NLRB v. Brown, 380 U.S. 278 (1965).

139. 102 S. Ct. at 2879.

140. Professor Davis has written: "The Supreme Court has explained the 'clearly erroneous' test in language which it would not use to explain the substantial evidence rule . . . K. DAvis, supra note 77, at 528 . He asserts that "[A] firm conviction of mistake [under 'clearly erroneous"] is closer to substitution of judgment than a firm conviction of unreasonableness [under 'substantial evidence']." Id. Thus, to the extent the two standards differ, Professor Davis apparently believes that "clearly erroneous" may actually provide a stricter standard of review than that imposed under "substantial evidence."

141. Although Justice Brennan determined that review of bankruplcy court decisions was under a "clearly erroneous" standard, that standard of review is not mentioned in the 1978 Act. Rather, the standard is nothing more than a judicially imposed gloss on the statute. See $102 \mathrm{~S}$. Ct. at 2863 n.5. 
quate basis on which to distinguish the functions of administrative agencies from the functions of legislative courts.

Further undermining Justice Brennan's rehance on differences in scope of review is the impliction in his Northern Pipeline analysis that appellate review in an article III court never satisfies the requireinents of article III. ${ }^{142}$ Logically, then, the scope of article III court review is irrelevant; no matter how strict, sucli review will not be constitutionally sufficient. ${ }^{143}$ Tlus, the Northern Pipeline decision fails to provide a sufficient basis to distinguish the constitutional status of administrative agencies from that of legislative courts. ${ }^{144}$

142. See id at 2879 n.39.

143. It should be noted, however, that Justice Brennan's opinion is internally contradictory on the question of the relevance of appellate review. Although he states in note 39 of his opinion that the availability of appellate review in an article III court does not satisfy constitutional requirements, at another point he einphasizes the differences in scope of review given to agencies and the bankruptcy court, implying that the distinction is of constitutional significance. Id. at 2875. At another point, he states that when Congress assigns adjudication of public rights to administrative agencies or to legislative courts, "it has generally provided, and we have suggested that it may be required to provide, for Art. III judicial review." Id. at 2871, $\mathrm{n} .23$ (einphasis added). This statement is puzzling for two reasons. First, if, as Brennan states in note 36 , the mere availability of appellate review in an article III court is insufficient to meet constitutional standards, why should the Court suggest that Congress "may be required to provide . . . for Art. III judicial review"? Second, if, as Brennan clearly concludes, "public" rights may be constitutionally adjudicated by non-article III bodies, what is the basis for suggesting that article III court review nnay be constitutionally required?

144. Professor Tushnet has also suggested grounds, for constitutional purposes, on which to distinguish the work of legislative courts froin the work of administrative agencies. He argues that

[t]he creation of administrative agencies authorized to exercise judicial functions can be jurtified . . . in two ways. First, the legislature may have delegated its functions to the agency through a broad command to regulate an area of society in which inany actors play their parts according to a constantly-changing script. It would be extreinely inconvenient at the outset to specify the detailed rules to govern the entire area committed to the agency . . . . Inertia in the legislature might prevent changes in the governing regulations designed to reflect a new balance of power. Some mechanisms must be devised to permit the agency to adapt, not only to new forms of behavior in the area with which it is concerned, but also to new contours of political power. Giving the agency the choice between rule-making and adjudication responds to the first of these considerations, and permitting the agency to take political factors into account in its adjudication responds to the second.

The second justification . . . is that it is just too unlikely that political considerations will influence the agency as it exercises its judicial functions.

Tushnet, supra note 33, at 950. Neither of these grounds justifies recognition of an exception to article II's mandate for administrative agencies. The first justification amounts to no nore than a coinpilation of pragmatic arguments, without an explanation of why or how such justifications can authorize a circumvention of article III. The second justification is neither intuitively nor einpirically supported, and in any event, as Professor Tushnet acknowledges, the second justification is "fundamentally inconsistent with the Framers' premises . . . ." Id. Tushnet adds, however, that "the argument is too well-established for me to ignore it." Id. Perhaps this is true, but it does not follow that we must accept it. 


\section{Determining the Constitutional Limits on Authority EXERCISED BY AN ARTICLE I BODY: ALTERNATIVE RATIONALES}

This article has demonstrated that the public-private right dichotomy is an inappropriate standard for determining the proper scope of authority to be exercised by article I bodies and that any standard will have an equal impact on federal administrative agencies and legislative courts because the two types of article I bodies are indistinguishable for constitutional purposes. When taken together, these conclusions underscore the theoretical inadequacy of Justice Brennan's standard and the practical importance of selecting an alternative standard. This section considers possible alternative standards and determines the practical impact of each on the work of federal administrative agencies.

\section{A. Justice White's Balancing Approach.}

In his dissent in Northern Pipeline, Justice White drew on the analysis in his opimion for the Court in Palmore v. United States, ${ }^{145}$ the decision that upheld the use of article I courts in the District of Columbia. Justice Brennan distinguishes Palmore on the ground that the decision's reach was geographically limited and therefore did not justify use of article I courts that are not geographically defined. ${ }^{146}$ Justice White, however, rejected this suggestion, ${ }^{147}$ arguing that the Court's decision to uphold the use of article I courts in Palmore "rested on an evaluation of the strength of the legislative interest in pursumg in this manner one of its constitutionally assigned responsibilities-a responsibility not different in kind from numerous other legislative responsibilities." 148 Thus, according to Justice White, although "[a]rticle III is not to be read out of the Constitution ... . it should be read as expressing one value that inust be balanced against competing constitutional values and legislative responsibilities." 149

145. 411 U.S. 389 (1973).

146. $102 \mathrm{~S}$. Ct. at 2874.

147. Id. at 2894 (White, J., dissenting). The holding in Palmore was not specifically geographically limited by the Court. See 411 U.S. at 408. The logic of the case should have been limited, however, to the use of article I courts within the District of Columbia. The argument in support of such a contention is that when Congress legislates for the District of Columbia, it is doing so in a manner analogous to that of a state legislature, and state legislatures are not controlled by the requirements of article III. The argument is flawed, because it disregards the fact that whenever it acts, Congress is subject to the requirements of article III. The argument, however, still presents the most narrow rationale for the Palmore decision.

148. $102 \mathrm{~S}$. Ct. at 2894 (White, J., dissenting).

149. Id. at 2893. 
Justice White is probably correct in his assertion that "such a balancing approach stands behind many of the decisions upholding Article I courts."150 Although Justice Brennan's opinion purported to distinguish, on other grounds, the article I status of both the territorial ${ }^{151}$ and military ${ }^{152}$ courts, ${ }^{153}$ ultinnately no ground, other than a desire not to inpose undue burdens on legislative and executive policies, can justify these results. ${ }^{154}$ Nevertheless, it does not follow that a balancing analysis-at least one so unprincipled as the ad hoc balance suggested by Justice White-provides the proper scope of authority of an article I body. The most obvious difficulty with the balancing analysis is that it does not appear to be authorized by the language of article III. The framers did not provide for an exception to the federal judges' salary and tenure protections should Congress find application of these protections burdensome or inconvenient. Indeed, it is likely that it is just such an approach that the framers attempted to avoid. It was assuredly no secret to the framers that insertion of these protections would restrict Congress; the framers apparently decided that such a burden was justified by the need to preserve an independent judiciary. ${ }^{155}$

An equally significant problem with Justice White's analysis is that the salary and tenure clause is one of the constitutional provisions least adaptable to a case-by-case balancing approach. A balancing approach requires the Court to weigh the legislative interest in freeing the government from the constraints of the salary and tenure protections against the competing interest in guaranteeing judicial independence. Such a balance will invariably favor the legislative interest because there is an inherent inequality in the weighing process: an immediately

150. Id

151. See, e.g., McAlister v. United States, 141 U.S. 174 (1891).

152. See, e.g., O'Callahan v. Parker, 395 U.S. 258 (1969); Reid v. Covert, 354 U.S. 1 (1957).

153. $102 \mathrm{~S}$. Ct. at $2868-69$.

154. See the discussion in M. REDish, supra note 8 at $37-40$. It does not necessarily follow, however, that even these pragmatic justifications provide a sufficient basis for the article I status of these courts. See infra text accompanying notes 159-62.

155. In previous writing, I have urged that a form of balancing process is a proper mode of interpreting the first amendment protection of free expression. See Redish, The Value of Free Speech, 130 U. PA. L. REv. 591, 622-25 (1982). There are important distinctions, however, between imterpretation of article III on the one hand and the first amendment on the other. First, as I have argued, the language of the first amendment does not dictate an absolute construction; it provides merely that Congress may not abridge "the freedom of speech," a term of art that is by no means self-defining. Second, if there is anything that is clear about the framers' intent in drafting the first amendment, it is that they did not contemplate anything approaching an absolute construction. Neither of these poimts is true of article III. Finally, the potentially severe harm that can result to society from total protection of expression makes the harm caused by an absolute cunsuruction of article III pale by comparison. See infra text accompanying notes 170-74. 
rccognizable, concrete interest is balanced against an interest wholly prophylactic in nature, and therefore one whose benefits will never be immediately recognizable. Without the salary and tenure protections, it is unlikely that there would be open and heavy-handed legislative and executive pressure on and threats against the judiciary. Indeed, there is little documented evidence of such pressure or threats in the state courts, where constitutional protections of salary and tenure rarely exist. Rather, salary and tenure provisions protect against subtle or unstated pressure on the judiciary. Presumably, it was because it would be virtually impossible to detect undue pressure that the framers chose to insert these prophylactic protections. Thus, any case-by-case balancing process will always tend to find the benefit of maintaining these protections illusory.

Justice White's opinion in Palmore provides perhaps the strongest evidence to support this conclusion. Justice White gave significant attention to the governmental interest im maintaining judicial flexibility in the District of Columbia ${ }^{156}$ but made no reference to the possible dangers of having judges in the District subjected to subtle or unstated pressure from governmental officials biving in the very saine locale. Justice White gave no consideration, for example, to the possible impact of a public statement by an important Congressman decrying the level of crime in Washington streets on the judges of the District's criminal courts. ${ }^{157}$ Granted, the likelihood of undue pressure is at best unpredictable, but again, that very reason probably prompted the frainers to insert the prophylactic salary and tenure protections in the first place.

Previous cases provide further support for the conclusion that a case-by-case balancing approach would invariably result in a finding in favor of the legislative interest. In each instance in which the Court has employed such an approach-either exphicitly or imphicitly-the colnpeting legislative interest has been relatively minimal, but nonetheless has proved victorious. It cannot reasonably be suggested, for example, that the nation would have been thrown into a state of financial or pohitical chaos if it had been held that the judges of the territories and of the District of Columbia must receive protections of salary and tenure. The saine can be said of the non-article III territorial courts. Admittedly, a traditional concern was that the judges of the territories performed the functions of both state and federal judges, Congress would not know what to do with many of these courts as the territories

156. See 411 U.S. at 408.

157. See 411 U.S. 389 (1973). 
became states. ${ }^{158}$ But, it is unlikely that the burden of paying a handful of unused judges as they lived out their years in retirement would tax the federal treasury for more than a small fraction of a single MX missile. Certainly, such a relatively minimal financial burden is not a justification for disregarding a clear constitutional command.

An argument might be fashioned that the legislative interests are more compelling for use of non-article III military courts. ${ }^{159}$ But the argument is largely overstated, ${ }^{160}$ and, more important, the need for formal protections of independence is probably at its greatest in the military context, where discipline and institutional loyalty are most intense. ${ }^{161}$ Interestingly, in striking the "balance" in favor of the constitutionality of article I military courts, the Supreme Court has failed to fully recognize this concern. ${ }^{162}$ This failure further supports the assertion that the use of a balancing approach in this context will invariably lead simultaneously to an overemphasis on the legislative interest and an underemphasis on the more elusive interest in prophylactically assuring judicial independence. .

The use of Justice White's balancing approach would make it easier for the Court to uphold the validity of administrative agencies. This would be true even if, as suggested lere, both the public-private right dichotomy and the asserted functional distinctions between agencies and legislative courts were rejected. Congress could reasonably conclude that it nceded both the expertise of the administrators and the flexibility to alter the membership, structure, and even existence of administrative agencies-interests that could clearly be undermined by imposition of the article III independence protections. Nonetheless, such an approach is blatantly inconsistent with both constitutional language and the intent of the framers and is likely to result in a virtually automatic validation of congressional circumvention of the salary and

158. See Glidden Co. v. Zdanok, 370 U.S. 530, 545-46 (1962).

159. See D. CURRIE, supra note 16 , at $42-43$.

160. As I have argued elsewhere, the choice is not between judges who sit at the whim of the government, on the one hand, and direct control by federal judges, on the other. The issue is, simply, whether those personnel who do hear military cases. . . will have their salary and tenure protected by Article III. Therefore, it is difficult to nnderstand how the exigencies of military discipline in any way require non-independent adjudicators. Certainly, the military system requires firm discipline, and on the battlefield the interest in having all the trappings of a due process hearing may be forced to give way. These facts, however, need not affect whether or not the individuals who hear the cases are independent of the prosecution.

M. ReDish, supra note 8, at 39-40 (footnote omitted).

161. Because of this fact, it is likely that if the military courts were held to require article III judges, such judges could not, as a practical matter, be full-time nembers of the military.

162. The Court has expressed concern over the lack of independent military judges, but ouly in the context of military adjudication of crimes by non-military personnel. See, eg., United states ex rel. Toth v. Quarles, 350 U.S. 11 (1955). 
tenure protections. The approach must therefore be rejected as a possible standard on which to determine the constitutional scope of authority exercised by article I bodies.

\section{B. The "Constitutional Issue" Alternative.}

One need not reject out-of-hand the concept of balancmg im order to reject the ad hoc variety of that test suggested by Justice White. Even if it were accepted that an absolute construction of article III is today impossible, the problem of consistent undervaluation of the judicial independence interest would still render Justice White's test invalid. A form of the balancing approach that might avoid the inherent bias of Justice White's approach would be one that focused a priori on the general types of cases in which the need for the independence protections is likely to be at its greatest. The approach would then carve out such cases as a constitutionally insulated enclave, not to be adjudicated by non-article III bodies. If it were accepted that the primary purpose of the independence protections is to avoid tyranny, ${ }^{163}$ the logical composition of this enclave would be those cases in which an individual asserts a constitutional right or raises a constitutional challenge or defense to governmental action. The threat of domination by the political branches of government, as well as of imposition of majoritarian tyranny, is greatest in such cases, for it is only such decisions which the political branches are unable to overrule through simple legislative action. It is therefore those decisions which the political branches are most likely to attempt to influence. Such a balancing approach would not focus on the asserted governmental justification for removing the salary and tenure protections. Instead, it would assume that if no constitutional right or issue is involved, there is no need for justification, and, conversely, if such a right or issue is involved, no justification for removing the protections is acceptable.

This approach might have led to a different result in Palmore because the local courts of the District of Columbia have authority to deprive individuals of their liberty and thus to rule on any constitutional defenses that might be raised. ${ }^{164}$ Similarly, the result in Northern Pipeline would probably have been different because it is not likely that

163. See 102 S. Ct. at 2864.

164. "Seeking to improve the performance of the [District of Columbia] court system, Congress, in Title I of the Reorganization Act, invested the local courts with jurisdiction equivalent to that exercised by state courts." Palmore v. United States, 411 U.S. 389, 392 n.2 (1973). Palmore itself was a criminal case, in which the Court upheld the local District of Columbia courts' jurisdiction. 
the bankruptcy courts face such issues. ${ }^{165}$ Whether administrative agencies could continue to function if this approach were applied would largely depend on the nature of the work of the individual agency. As long as Congress limits the agency to enforceinent of its statutory mandate and does not give it authority to adjudicate constitutional challenges to the statute, the courts will probably hold the existence of the agency valid.

Of course, even though an agency or legislative court does not have power to rule on specific constitutional challenges, the result of the work of the agency or court might well be to deprive a private individual or entity of property. For example, if the Federal Trade Commission orders a corporation to cease and desist from advertising in a particular manner, the corporation could, as a result, suffer economic damage. If the Commission does so im a manner not authorized by its enabling statute-if the advertising was not deceptive, for examplethe agency has arguably deprived the corporation of property without due process of law. But although such action inay technically amount to a constitutional violation, it is arguable that the "constitutional issue" doctrine should not bar the use of non-article III bodies in such a situation. As long as Congress could have constitutionally outlawed the conduct in question, the need for judicial imdependence is not as pressing as it is in a situation in which Congress has allegedly gone beyond its constitutional powers.

Under this approach, then, the essence of the article III protections would be preserved by requiring an article III court to adjudicate all direct constitutional challenges to actions of the federal government. ${ }^{166}$ In past writing, I have suggested-in brief form-an analysis similar to the one just described. I still believe the approach to be far superior to the alternative standards adopted by Justices Brennan and White in Northern Pipeline. ${ }^{167}$ Upon reflection, however, it appears to ine that the "constitutional issue" analysis is seriously-and perhaps fatallyflawed. ${ }^{168}$ If so, it may be that the only acceptable alternative is an absolute bar on the use of non-article III federal bodies ${ }^{169}$ for at least

165. Of course, to the extent such a question were raised in the course of a bankruptcy adjudication, it could be left for de novo decision in the article III reviering court.

166. This conclusion must, of course, be tempered by the clearly established congressional ability under article III, section 1 to vest such issues in state courts. But see infra note 169.

167. See supra text accompanying notes 44-52, 145-49.

168. See infra text accoinpanying note 170.

169. It is, of course, well accepted that Congress could have chosen to vest all of the federal judicial power in the state courts. See, eg., Lockerty v. Phillips, 319 U.S. 182, 187 (1943). However, it does not logically follow that Congress may instead choose to circumvent the article III courns by vesting the judicial power in non-article III federal bodies. The important difference 
the final adjudication of any case falling within the "judicial power," as defined in article III, section 2.

\section{The "Absolute" Alternative.}

The "constitutional issue" approach effectively carves out an enclave of cases within article III's "judicial power" that cannot be given for adjudication to non-article III bodies. This approach accomplisles the purposes of the article III protections far nore sensibly than does an approach that establislies an enclave consisting of common law suits between private individuals. The "constitutional issue" approacl is also superior to a case-by-case balancing process that provides no enclave that is safe from congressional subversion.

The problem with the "constitutional issue" approach, however, is that the terms of article III do not suggest merely the existence of an "enclave," whatever its content. Rather, from its language, the article appears to tolerate no exceptions to its requirements. Article III vests the "judicial power" in judges formally independent of the other branches of the federal government, and then describes that power in the very next section. The Constitution does not provide that only federal judges adjudicating cases presenting constitutional issues must have these independence protections, and it most assuredly does not stipulate that only those federal judges hearing state-created common law suits between private individuals must have such protections. Although most of the Constitution's provisions leave substantial room for modernizing interpretation, ${ }^{170}$ article III does not. The argument in favor of an absolute construction of article III, then, is that there simply exists no primcipled alternative. If the framers had so desired, they conld easily have carved out an enclave; they chose not to do so.

Adoption of an absolute construction of article III would not necessarily mean an end to the use of legislative courts or administrative agencies. Of course, because article III apphes only to "cases," this construction would not bar agency rulemaking. But it need not necessarily follow that such agencies would be barred from adjudicating, even though their members do not have article III protections and the cases that they adjudicate inescapably fall within the "judicial power," as cases arising under the laws of the United States.171 The obvious

between such bodies and state courts is that the latter are, in effect, as free from congressional authority to regulate their salaries and tenure as are the article III courts. The same is not true of untenured non-article III federal bodies.

170. A classic illustration of this principle is the due process clause. U.S. Const. amends. V, XIV. See generally Roe v. Wade, 410 U.S. 113 (1973).

171. U.S. CoNST. art. III, \& 2. 
escape route is to rely on the availability of effective appellate review in an article III court, a route that Justice Brennan explicitly rejects without satisfactory explanation in Northern Pipeline. ${ }^{172}$ Justice Brennan bases his rejection on the language of article III, which, he empliasizes, provides that the judges of both the supreme and inferior federal courts shall have the protections of independence. ${ }^{173}$ Nevertheless, if in every case falling within the judicial power there exists an opportunity for review in an article III court, it would seein that the constitutional requirement that the judicial power "be vested" in these courts is fully satisfied.

If appellate review satisfies article III's requirements, surely that review inust be a ineaningful one. An absolute construction of article III would therefore dictate a tightening in the scope and level of appellate review of the findings and conclusions of administrative agencies. Whether there is "ineaningful" review under the highly deferential "substantial evidence" test is questionable. It is true, as Chief Justice Hughes pointed out in Crowell, ${ }^{174}$ that the existence-indeed, constitutional status - of juries as fact-finders within the article III court system demonstrates that the framers conteinplated the use of non-article III personnel to perform fact-finding tasks. Tlus, a limited standard of review for administrative factual findings might be appropriate. ${ }^{175}$

On the other hand, it should be recalled that although jurors do not retain article III protections of salary and tenure, they are not controlled by any branch of the federal government, and indeed are traditionally relied upon as a protection against governmental tyranny. It therefore seems inappropriate to analogize juries to non-article III federal adjudicatory organs. It would not necessarily follow, lowever, that an absolute construction of article III would require the holding of de novo judicial proceedings in the reviewing court. It is reasonable to assume that the reviewing court could satisfy the obligations of article III by employing nondeferential review of agencies' interpretations of their statutory inandate as well as their application of statutory require-

172. In a footnote, Justice Brennan rejected the argument "that Art. III is satisfied so long as some degree of appellate review is provided." He reasoned that the "suggestion is directly contrary to the text of our Constitution" and that "[o]ur precedents make it clear that the constitutional requirements for the exercise of the judicial power must be met at all stages of adjudication, and not only on appeal, where the court is restricted to considerations of law, as well as the nature of the case as it has been shaped at the trial level." 102 S. Ct. at 2879 n.39. As already noted, however, at other points in his opinion Brennan implied that much turned on the availability of article III court review. See supra note 143.

173. 102 S. Ct. at 2879 n.39.

174. 285 U.S. at 51.

175. Compare Crowell v. Benson, 285 U.S. 22 (1932) with St. Joseph Stock Yards Co. v. United States, 298 U.S. 38 (1936). 
ments to individual facts, and by reviewing with greater care than previously used an agency's primary factual findings. The court might still be allowed to take into account, as virtually a matter of common sense, the existence of agency expertise, but no longer could the reviewing court effectively abandon the performance of its functions to an agency on the ground that the agency has greater familiarity with the subject matter.

\section{Conclusion}

The restrictions on the work of administrative agencies resulting from an absolute interpretation of article III would not only impose significant new burdens on the federal court but might significantly disrupt the work of the modern administrative system. Nonetheless, a principled construction of inescapably clear constitutional language cannot turn on such pragmatic factors, and a simple response to the pragmatic arguments might be that if the clear dictates of the Constitution are untenable for modern times, the Constitution should be amended. Many scholars and jurists might find the amendment alternative to be at best unrealistic. They might remind us that the Constitution must be allowed to develop to meet the needs of the times. Although this is trne for such broadly phrased constitutional provisions as due process and interstate commerce, the requirenents of article III do not lend themselves to such linguistic mampulation.

Justice White argues in his Northern Pipeline dissent that "[w]hether fortunate or unfortunate, at this point in the history of constitutional law . . . [the] question [of what limits article III miposes on Congress] can no longer be answered by looking only to the constitutional text."176 We are not free, he suggests, "to disregard 150 years of history . . . ."177 There is, I suppose, inuch force to this argument. Perhaps it is simply too late in the day to suggest an absolute construction of article III; a distinguished-if largely confused and unprincipled-line of cases has taken us well beyond that stage. The Court, however, has adopted no clear alternative analysis in all of those 150 years. Perhaps the confusion engendered in all of those decisions deinonstrates that an absolute construction-combined with recognition of the constitutional adequacy of appellate review-provides the only possibility for a consistent and primcipled interpretation of article III. But for those who are convinced by Justice White that an absolute construction is, for one reason or another, today untenable, the most ap-

176. $102 \mathrm{~S}$. Ct. at 2883 (White, J., dissenting).

177. Id 
propriate alternative is the "constitutional issue" analysis. Although this approach departs from the clear command of the constitutional language, it nevertheless comes closest of any of the non-absolute alternatives to achieving the framers' wisely chosen original purposes for the article III protections of salary and tenure. 
